DOI: $10.15503 /$ jecs20142.180.192

\title{
POLITICAL ISSUES IN CONTEMPORARY ART OF UKRAINE
}

\author{
NATALIA USENKO \\ Kharkiv State Academy of Design and Arts, Chervonopraporna Str. 8, \\ Kharkiv, Ukraine \\ E-mail address: mailukr@mail.ru
}

\begin{abstract}
At the beginning of the XXI century Ukrainian art observed activization of the artist's interest for the political life of the country. The starting point was 2004, marked by protests against unfair elections in the country, the birth of the first "Maidan" and "Orange revolution". In a number of artistic actions organized by art groups we can see the reflection of the revolution events and, later, the frustrations of its ideals.

The most striking manifestation of political issues in contemporary art in Ukraine was the great creativity following the second "Maidan" (2013). In this spontaneous Performance everyone plays a role: the participants are the protesters, official persons, fighters of "Berkut" and interior force troops, journalists and others. Protesters' tents, barricades, a statue of Lenin and "Maidan" itself (or Independence Square) as a place of free will and creativity became the Symbols of the "Maidan" and its own art objects.
\end{abstract}

Keywords: Contemporary art, politics, political actionism, "Maidan", Ukraine, artistic life, exhibitions.

\section{INTRODUCTION}

The 2000's in contemporary art of Ukraine were noted with big changes: activization of artistic life began and was accompanied by various art events. One of the most distinctive features of contemporary art was actualization of political subjects in various art forms, which was a reaction to the events in the political life of the country on her way to democracy.

Most clearly political art came to light during the events of 2004 and 2013-2014, when in Ukraine massive actions of protests in the name of democracy were held. These revolutionary events were called "Maidan" (2004) and "Euromaidan" (2013) because it started on Independence Square in Kyiv (from Ukrainian the word "Maidan" translates as "Square").

It should be noted that in 2004 and in 2013 those protests on Maidan were supported by a significant part of Ukrainian intellectuals. In various activities many Ukrainian artists participated, expressing their civic and political stands in a number of artistic projects and works.

The aim of this study is to investigate the features of the art of protest in Ukraine, to analyze the most important artistic projects, to determine their influence on contemporary artistic process. 


\section{FINDINGS}

Political issues in the national art developed vividly and variously since Ukrainian Independence (1991). However, the growing interest of artists in this phenomenon has been observed since 2004, when Ukraine has increased democratic tendencies, and not only de jure but also de facto the free expressions had become possible. Then, during the "orange" revolution of 2004, a number of works for which the term of "modern revolutionary art" began to be used were created. It was not only the "traditional" paintings or graphic, photographic works, but also unusual art objects, indispensable attributes of the first Maidan - "American" boots, painted polyfoam plates and "injected" oranges (Daniuk, 2005).

Then on the wave of the revolution in different cities appeared bright politically oriented youth art groups, the most active among them were "R.E.P" (Kyiv) and "SOS'ka" (Kharkiv). It is significant that in the capital the statements of "R.E.P" artists existed in opposition to the tradition of painting, artists of art-group "SOS'ka" in Kharkiv relied on existing traditions of nonconformist school of social photography.

One of the earliest and most famous projects of art-group "SOS'ka" is a series of events " "They» on the street" (see Figure 1), where the ironic criticism of artists revealed all the candidates in the presidential race - Viktor Yushchenko, Viktor Yanukovych and Yulia Tymoshenko. In this event artists looking like homeless people and with masks of Ukrainian politicians were begging for money. In this way they wanted to demonstrate their point of view on the state of the current political system in Ukraine. Asking for money in this project had become a metaphor for the direct methods, by which candidates used to receive votes - massive media campaigns. These events of young artists had wide response, because their critical position coincided with the sentiments of society after the Maidan (Kriventsova, 2008).

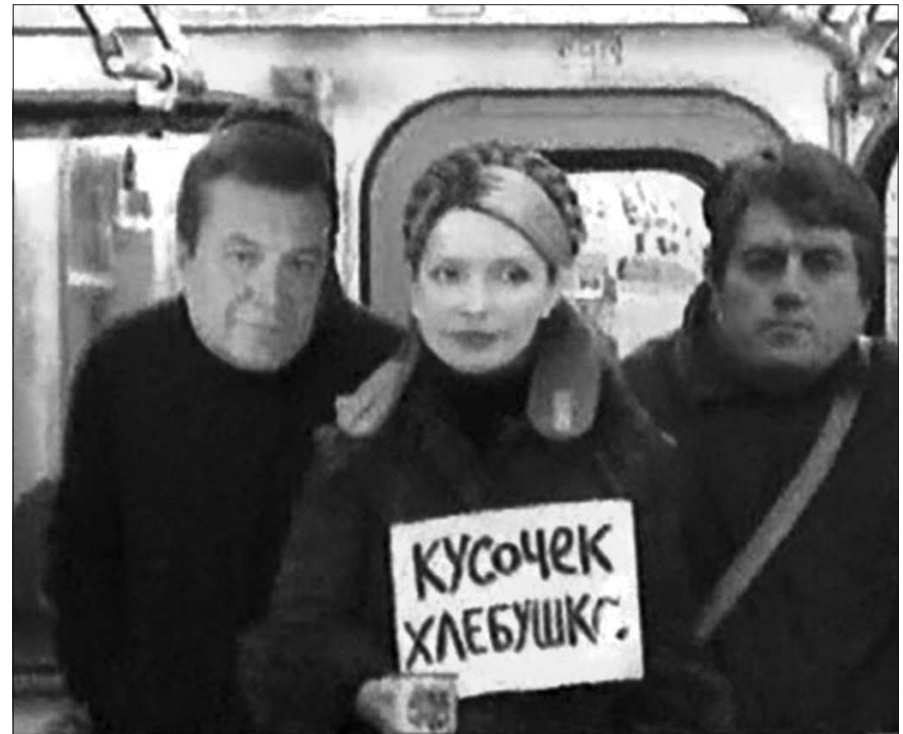

Fig.1. «SOS'ka» group. ««They» on the street». 2006.

Successive events of this art-group demonstrated the impact of policy on every common man and marked the need to join the fight against the absurd political pressure. The general state of the people in the first days after the Maidan found its reflection in the exhibition "Favorites", where a number of portraits of dogs and cats with propaganda slogans opposed to a series of pets cemetery. In the context of political events the project "Ukrainian Gothic" (see Figure 2) became interesting, where 
artists presented to the public the modern heroes - "goths" and "emos" who pose with the Ukrainian flag, a portrait of the Ukrainian poet Taras Shevchenko and Soviet boards of honor in the background. In a series of photos the artists ironically show the indifferent face of modern Ukrainian patriotism: young Ukrainian students who are not interested in politics and who have only a local state existing within their narrow society (Ridny, \& Kriventsova, 2009).

It should be noted that during the first years of the XXI century bright politically oriented projects and events of young artists gradually influenced the formation of the artistic society. However, this process was quite slow, and traditional institutions continued to demonstrate a valid format of thinking without taking seriously modern works of young artists. A good example of the conflict between new and old art was the exhi-

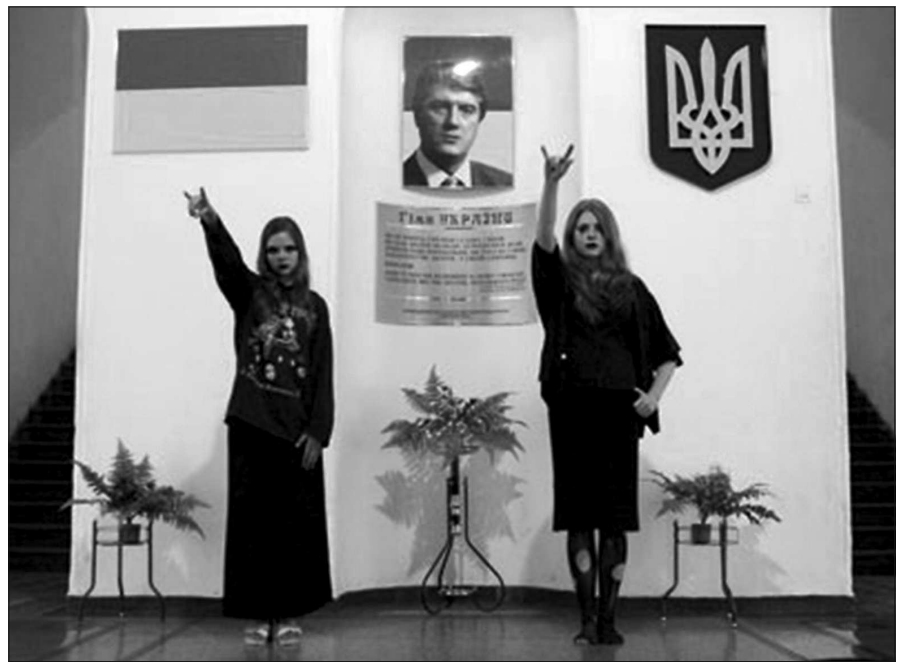

Fig.2. «SOS’ka» group. «Ukrainian Gothic». 2007.

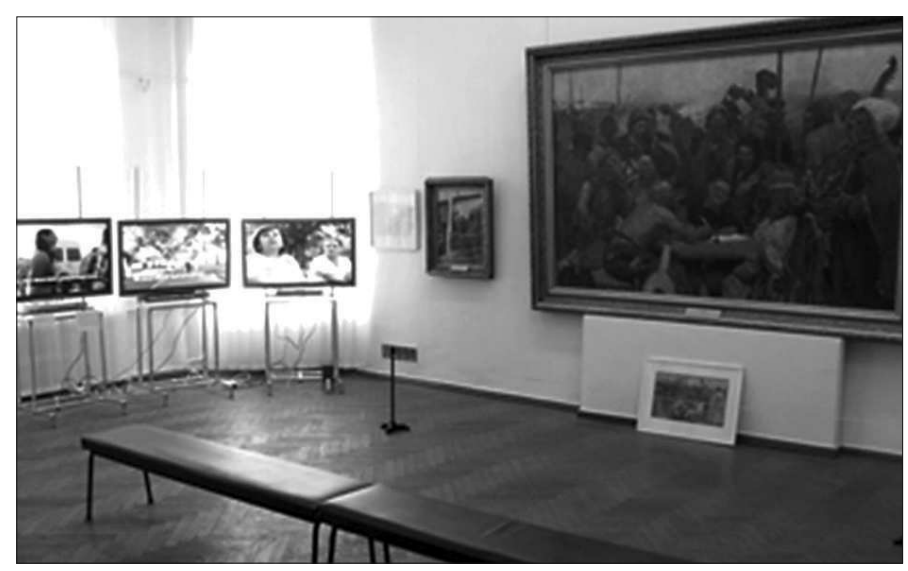

Fig.3. A. Vayndorf. «Detour. One particular Sunday». The «New History» exhibition. 2009.

bition "New History" (2009) (see Figure 3), created with support of Foundation "Eidos" in the Kharkiv Art Museum and where the main goal was to create an artistic dialogue by opposing the works of classical and contemporary art. In this project well-known representatives of the young generation artists participated: N. Ridny, A. Kriventsova, Z. Kadyrova, A. Vayndorf and others. By the way, the work of the latter, as well as other projects within the exhibition, was seen by the museum administration as an insult to the symbols of Ukrainian history. The next morning the exhibition was cancelled because the Director of the Museum found them obscene and not corresponding to the museum policy. This event was significant in the context of understanding in the developing modern Ukrainian art of the role of art institutions, who even in the beginning of twenty-first century continue to work on the principles of dead socialist realism. 


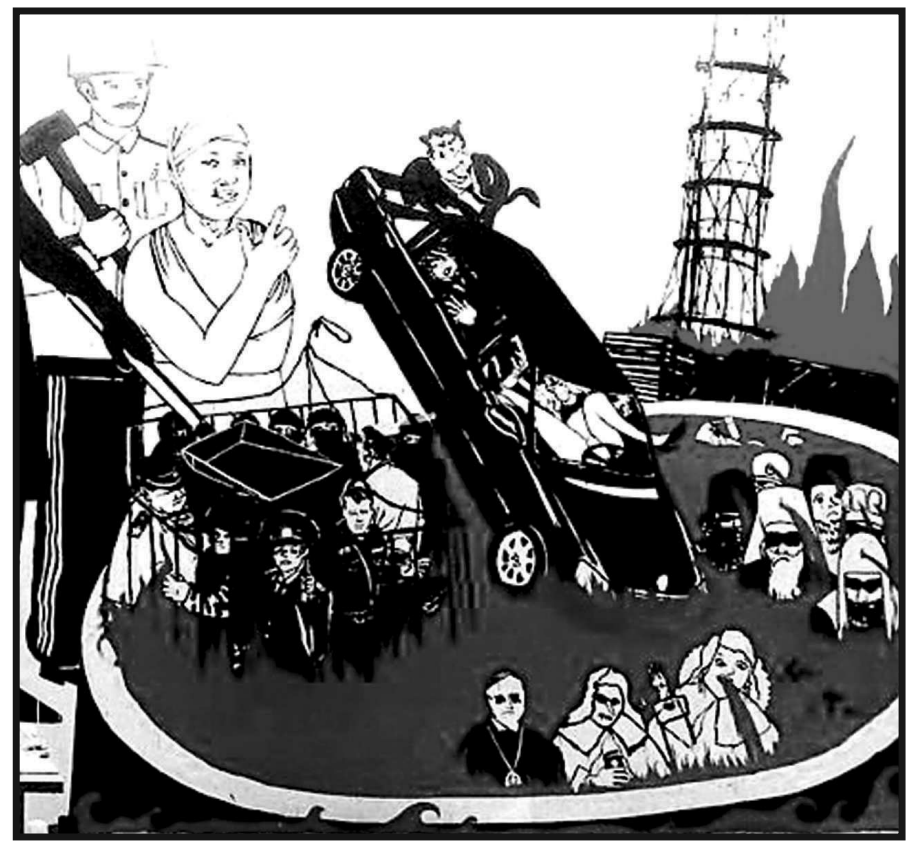

Fig.4. V. Kuznetsov. «Koliivshina. Last Judgement». 2013
A similar situation occurred in 2013 during the opening of the exposition "Great and majestic" in "Art Arsenal" (Kyiv), where a number of modern Ukrainian artists works were exhibited. On the day of opening the director of "Art Arsenal" N. Zabolotnaya before the arrival of the official persons led by President Viktor Yanukovych, painted black the work of V. Kuznetsov “Koliivshina. Last Judge-

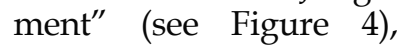
where was ironically revealed a painful subject of Ukrainian corruption of all levels - from police and officials to the priests. This action the director explained by her wish to create "her own performance", saying that "nobody can criticize the Motherland" and named the work of V. Kuznetsov a "slap" and "provocation against the audience of the exhibition", considering, probably, the high society circles ${ }^{1}$ [4].

This event for Ukraine has become quite symptomatic. The behavior of the curator of the exhibition showed not only her lack of professionalism as a leader of one of the most popular exhibition areas of the capital, but also highlighted the lack of civilized view on the development of modern Ukrainian culture, a derogation from the democratic and moral principles and strengthening of the country's censorship. Moreover, according to some critics, this act of vandalism allowed the occurrence of another, more important work of understanding and verbalization of basic concepts of contemporary artistic practice and its institutional (political) function. This is how a incomplete mural of V. Kuznetsov was transformed into a collective media performance.

The most striking and inconsistent works were created during the Ukrainian democratic revolution of 2013-2014, started by the event in support of European integration called "Euromaidan". Civil resistance to the regime, powerful impulses to achieve freedom and justice were reproduced in works of art. On Euromaidan almost all important in Ukraine directions and genres of contemporary art were shown: performances, art events, flash mobs, installations, almost all types of graphic design, as well as more traditional painting, drawing, photography and more. One of the first movable art objects of Euromaidan became the base of the Kyiv Christmas tree, decorated with political propaganda posters and ribbons with the symbols of the European Union and the Ukrainian flag. 
This tree was the first formal reason for the struggle between protesters and authorities who, in an attempt to disperse Euromaidan, proclaimed to be freeing the square for the reason to prepare it for a holiday time. Art critic V. Ibrayeva described the process like this: "handmade as well as printed posters are hung on the base of Christmas tree, and as a response to its partial dismantling, Facebook demotivator demonstrated a little girl with poster "Choke on your Christmas tree". So, after the protesters and forces collisions that tree became a symbol of freedom of expression (Ibraeva, 2013).

Interesting art objects and symbols of the first days of Euromaidan were handpainted orange miner's helmets ${ }^{2}$, which immediately marked a vivid image of Euromaidan protesters. From the beginning of the protests, they were used by activists as the first defense against attacks of "Berkut" forces and provocators, so-called

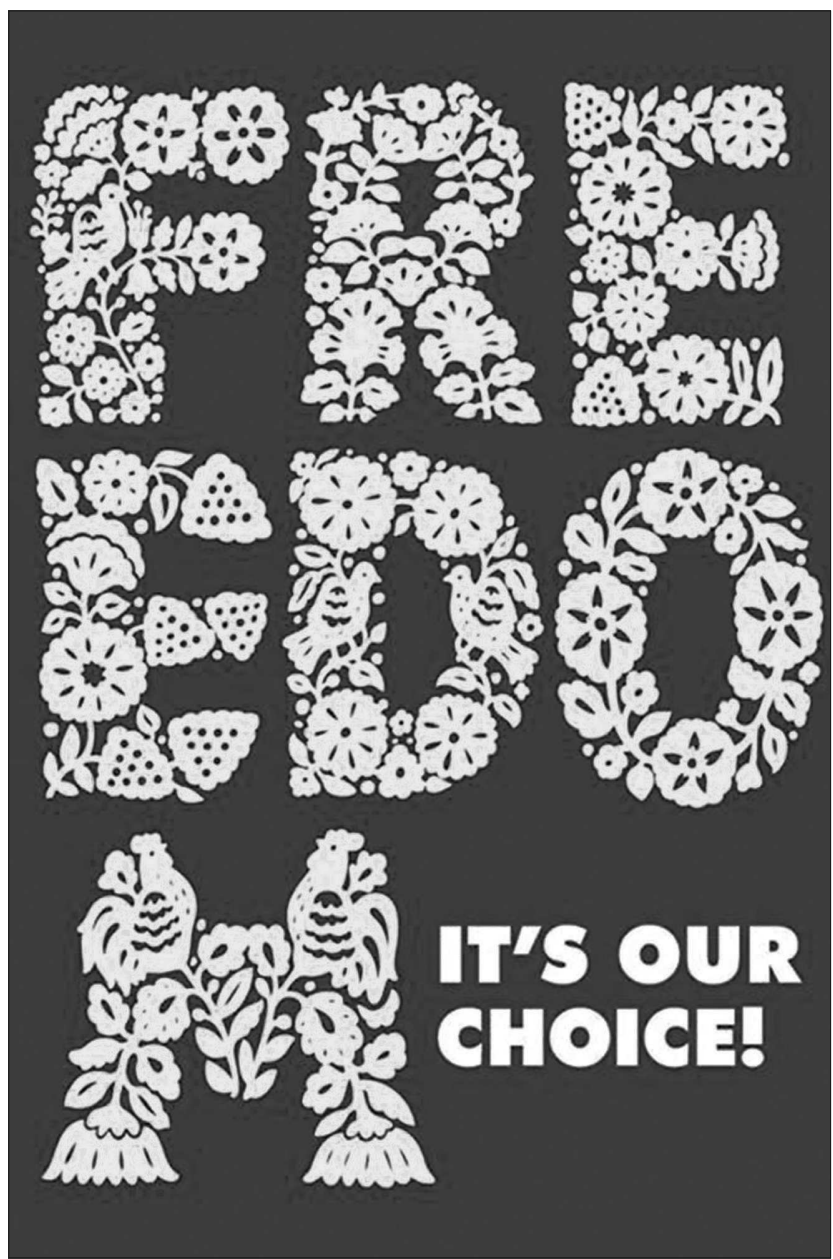

Fig.5. O. Selisheva. «Freedom». 2013. "titushko".

Designers were one of the first who responded to the events of Euromaidan and produced a series of posters dedicated to the European integration movement ${ }^{3}$. At that time also the first photographic and artistic works were created. It should be noted that all the works of art of that period were marked by patriotic romantic mood, full of inspiration and hope. Most of them were made using symbolic colors - yellow and blue, which showed a friendly color combination of the Ukrainian and the EU flags (see Figure 5).

Igor Bilynsky etc.

3 The most popular project of designers was the «Strike Placate» art-society. More details you can see on the facebook page: https://www.facebook.com/strikeposter 


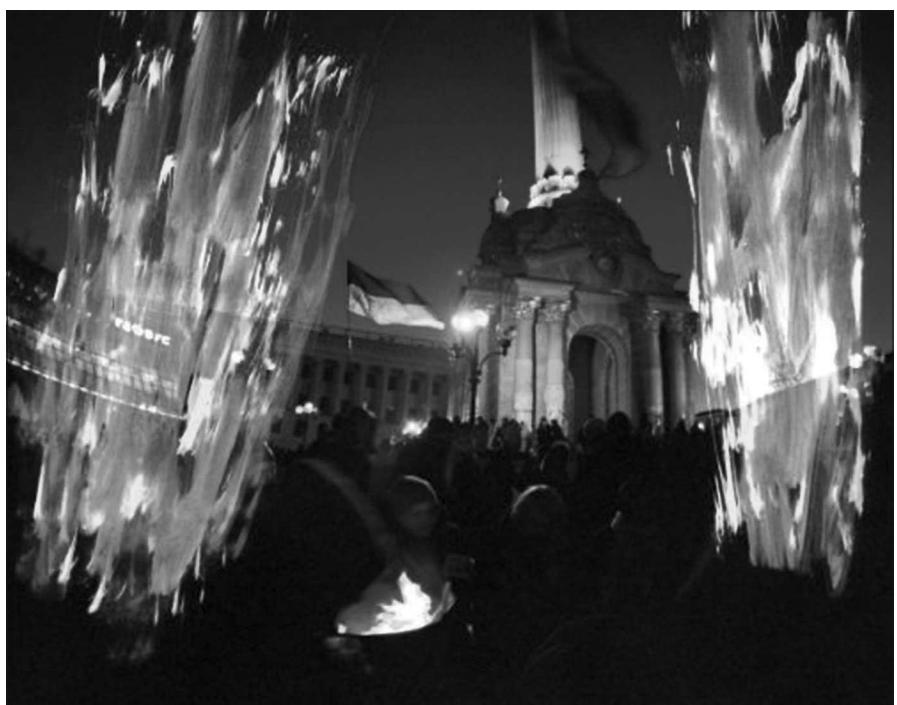

Fig.6. R. Minin. «Bonfire of Maidan». 2013.

In similar colors were made photo series of Kharkiv artist Roman Minin" "Bonfire of Maidan" (see Figure 6). There were painted films depicting various demonstrations on Independence Square. These photos were taken at different times and on various events on the Maidan. The main character surely is the Square as a symbol of Ukrainian freedom. In these photos the beauty of Kyiv and protesters union were revealed (Balashova, German, \& Lanko, 2013).

The first period of Euromaidan include original design colored sticker sets, resembling chewing gum wrappers "Love is ..." (see Figure 7), where the authors (Vasylyna Duman \& others) promoted a positive goal of Euromaidan and explained that the character of protests is peaceful. They listed many reasons to find the strength and courage to express loudly a desire to be a part of European society. The main characters of stickers are peaceful and romantic Ukrainian boy and girl who want peace most of all, even with "titushkos"
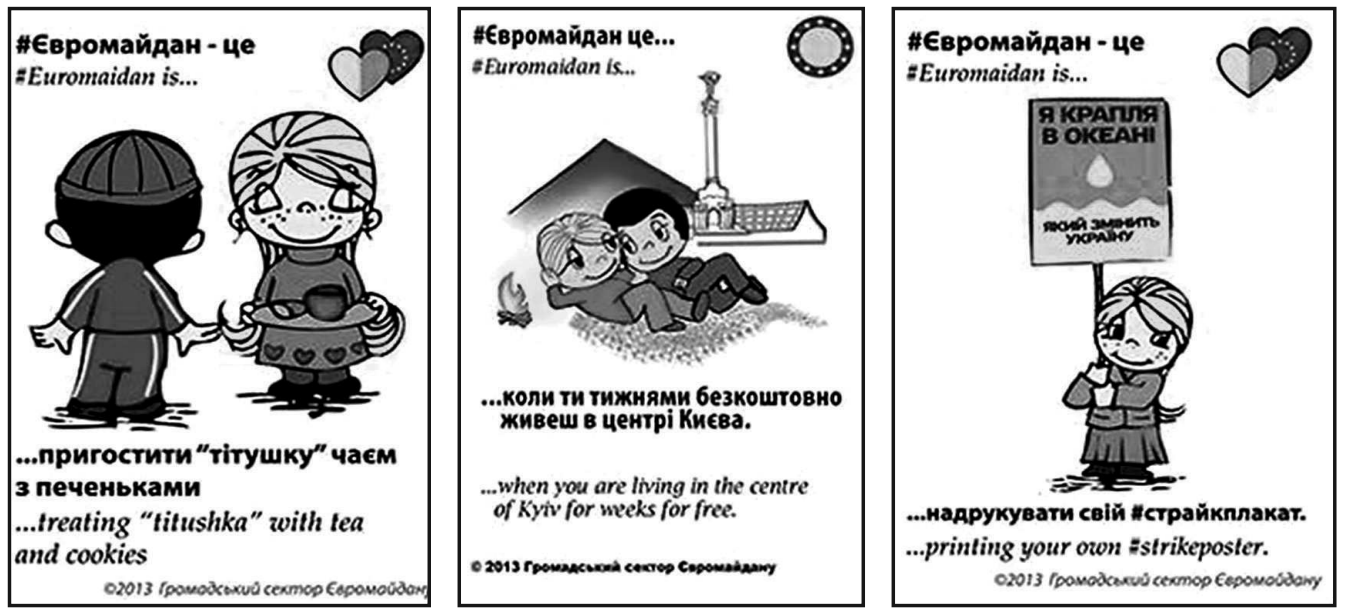

Fig.7. V. Duman \& co. «Love is ...» sticker-set. 2013.

$4 \quad$ Roman Minin also known in Kharkiv as a street-art artist. More details about his work you can see here: http://mininstreet.blogspot.com/

5 More details about this project you can see here: http:// perevozchik00.livejournal.com/31475.html 
After the first violent dispersal of protesters, artwork shifted to depressive and ironic forms. Like this was the gloomy and restrained "Reward for silence" of Kharkiv's artist R. Minin (see Figure 8), ironic "Hero of Our Time" about "titushko" from Alexander Ermolenko (see Figure 9), "Student Day" of Yurij Zhuravel (see Figure 10), etc.

Subjects of all these works gradually became more militant, demonstrating the despair, hurt and offense of activists by the actions of the current government. However, most of the main characters of these creations are the same young, smart and friendly boys and girls who are still hoping for a peaceful settlement of the conflict.

A considerable symbol of democratic struggle in Euromaidan was the project "Art Barbican". Barbican serves as a fortification of the castle, fortress or city walls. So now, in the same form the organizers imagined the art-checkpoint of creative intellectuals gathered by the efforts of the art-association "Last Barricade".

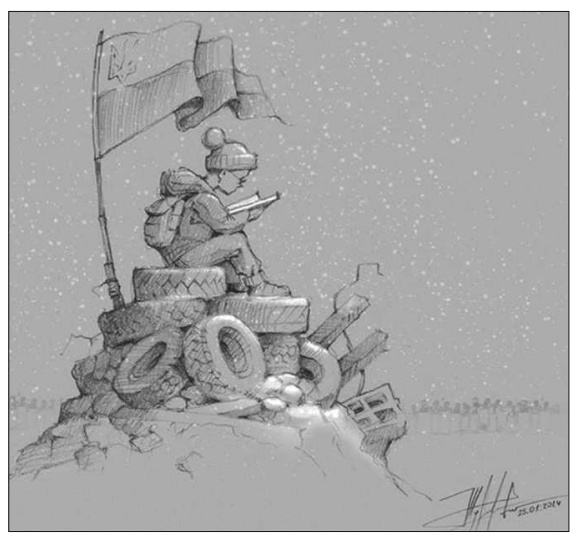

Fig.10. Y. Zhuravel. «Student Day». 2014.

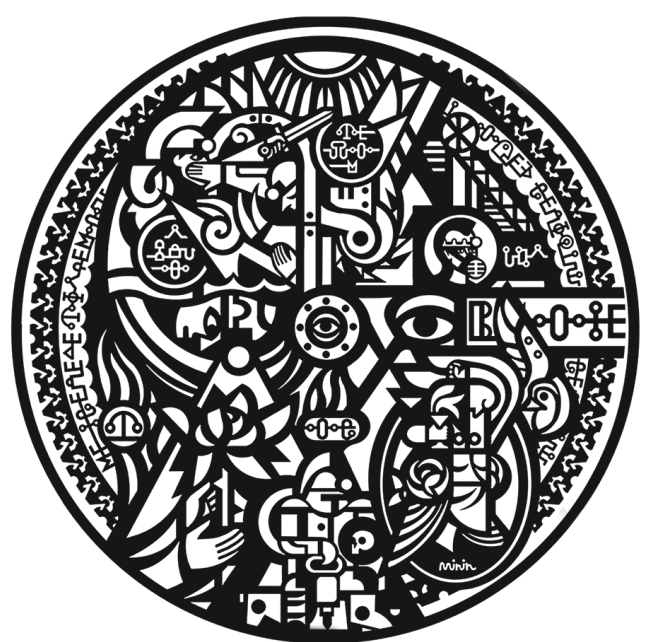

Fig. 8. R. Minin. «Award for Silence», 2014

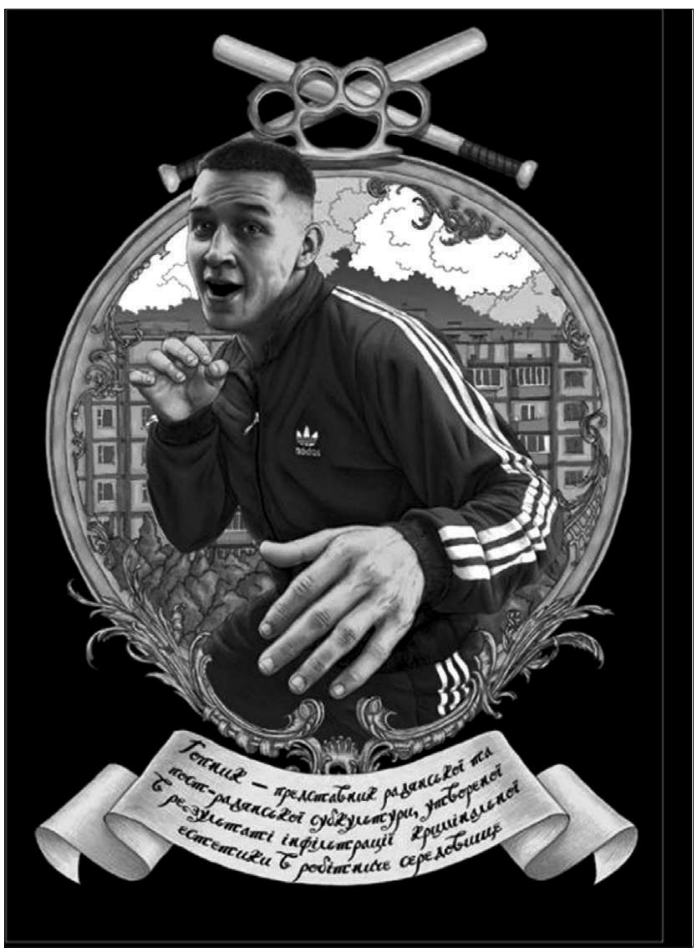

Fig. 9. A. Ermolenko. «Hero of Our Time». 2013. 


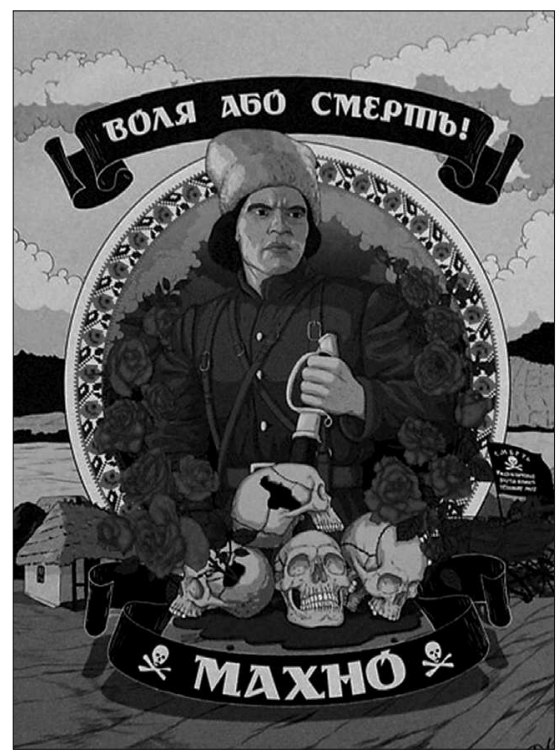

Fig. 12. A. Ermolenko. «Makhno». 2013.

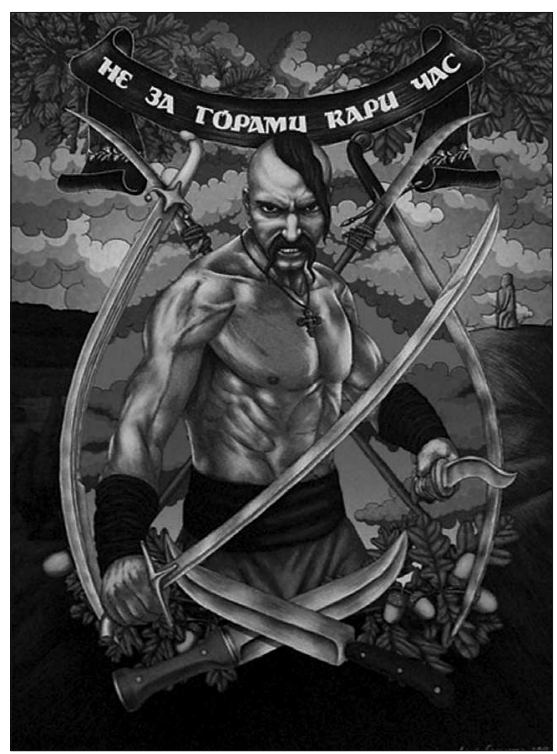

Fig. 13. A. Ermolenko. «Time of punishment is not far off». 2013.
On the walls of "Barbican" were presented art prints of artists Ivan Semesyuk, Andriy Ermolenko, Oleksa Mann, well known by their co-work with the "Jerk-art". In this project young authors had used images of Ukrainian poet, artist and freedom fighter Taras Shevchenko (see Figure 11), revolutionary Nestor Makhno (see Figure 12) and protester of Euromaidan Mychaylo Hawryluk (see Figure 13), who became to protesters and supporters of Euromaidan the symbols of national ideas awakening ${ }^{6}$.

During Euromaidan a number of significant performances, events and flash-mobs supporting European integration and expression had passed. For example, on Kharkiv Euromaidan was organized an ironic art flash-mob "Area of Freedom" (see Figure 14) near the fence built around the Freedom Square. The main idea of this action was to point on the fact that freedom in Kharkiv is locked in all the senses of the word.

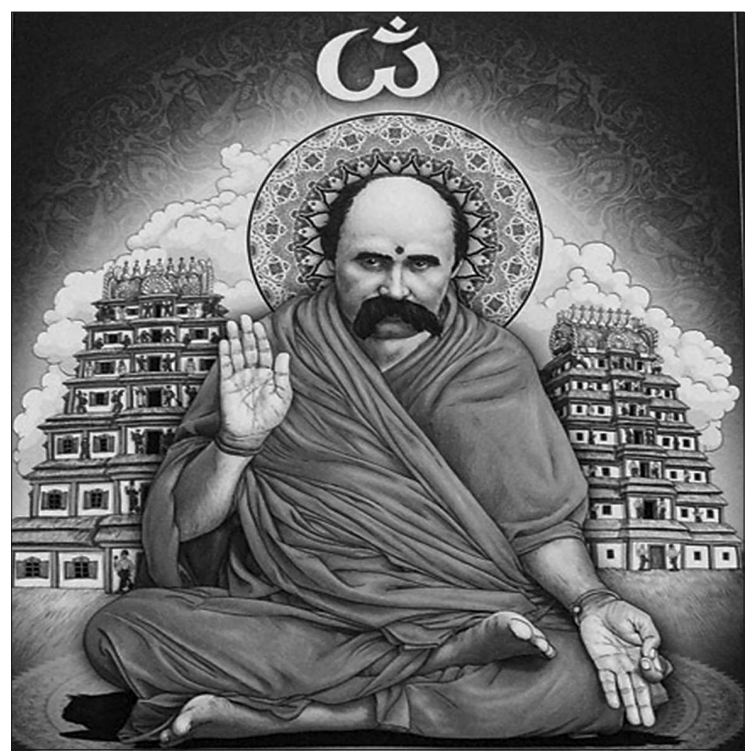

Fig.11. A. Ermolenko. From «Shevchenkiniana». 2013.

6 More pictures and details about «Barbican project»: http:/ / artvertep.com/print?cont=24181 


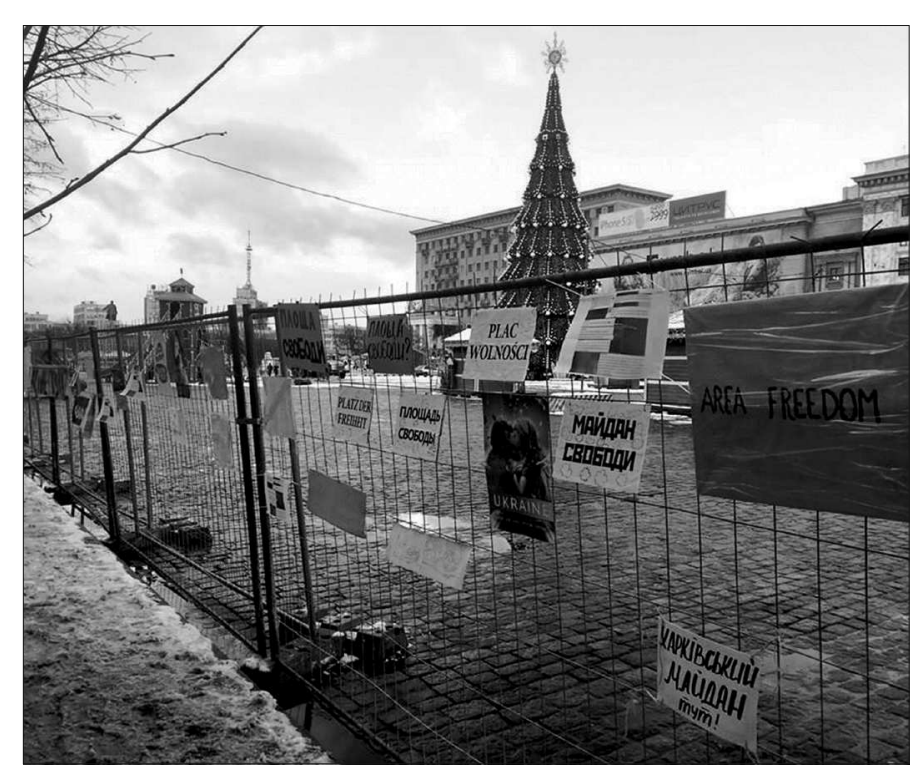

Fig. 14. «Area of Freedom». Artistic flash-mob in Kharkiv. 2013.

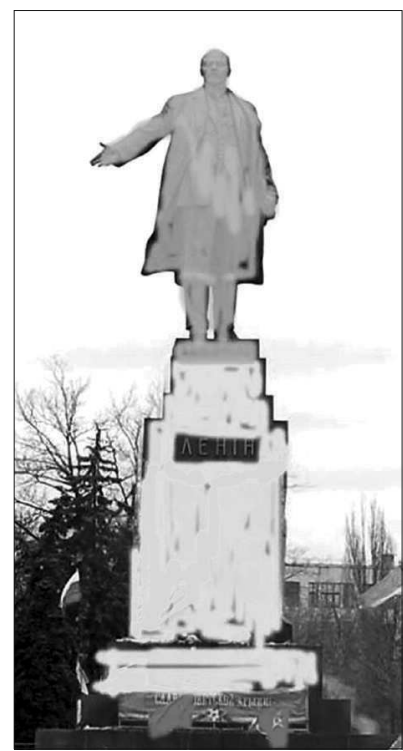

Fig. 15. B. Logacheva. «Lenin in yellow-blue». 2014.

On the way towards Ukrainian democratization also the actions of pulling down of the monuments of Soviet leader Vladimir Lenin were important, which became a symbolic sign of sweeping out of the Ukrainians' life of the communist regime ${ }^{7}$. However, many citizens of the country did not understand this ceremony of renovation. Art-critic V. Ibrayeva noted that "the dumping of the Lenin monument in Kiev equated the actions of Maidan supporters to the actions of the Soviet Bolsheviks, who once tried to change history by destruction of monuments, architecture and art"(Ibraeva, 2013). Kyiv artist $\mathrm{O}$. Roitburd said that the monument did not need to be destroyed, but only to be removed to another location (Ibraeva, 2013). Fighting with the symbol of communism in many cities of Ukraine ended with the victory of protesters. Only in the eastern regions Lenin monuments remained in place. Ironically, in this case can be considered an example of the Kharkiv Lenin monument, which was not destroyed because of the aggravation of the social situation in the city. This residue of totalitarianism, clearly is an antagonist to Freedom Square, where it is located. However, activists of the Kharkiv Maidan had accepted just superficial changes. For example, in work of Bella Logacheva the artist offers to repaint the monument in the colors of free Ukraine (see Figure 15).

Existing for some time as epicenter of Ukrainian cultural life, within which a large number of art works and projects were created, Euromaidan itself became a newborn island of Ukrainian democracy, a place and a symbol of freedom in the country. Analyzing the art-works of Euromaidan we draw attention to the importance of this event in the context of the artistic process. Thus, the whole Independence Square becomes, by definition of the Russian artist P. Pavlensky, a "total installation": "On the Maidan

$7 \quad$ Despite the historical value of certain sites, Lenin, who was the symbol of the totalitarian regime in the post-Soviet Union area, had become a necessary symbolic victim of this important process. 


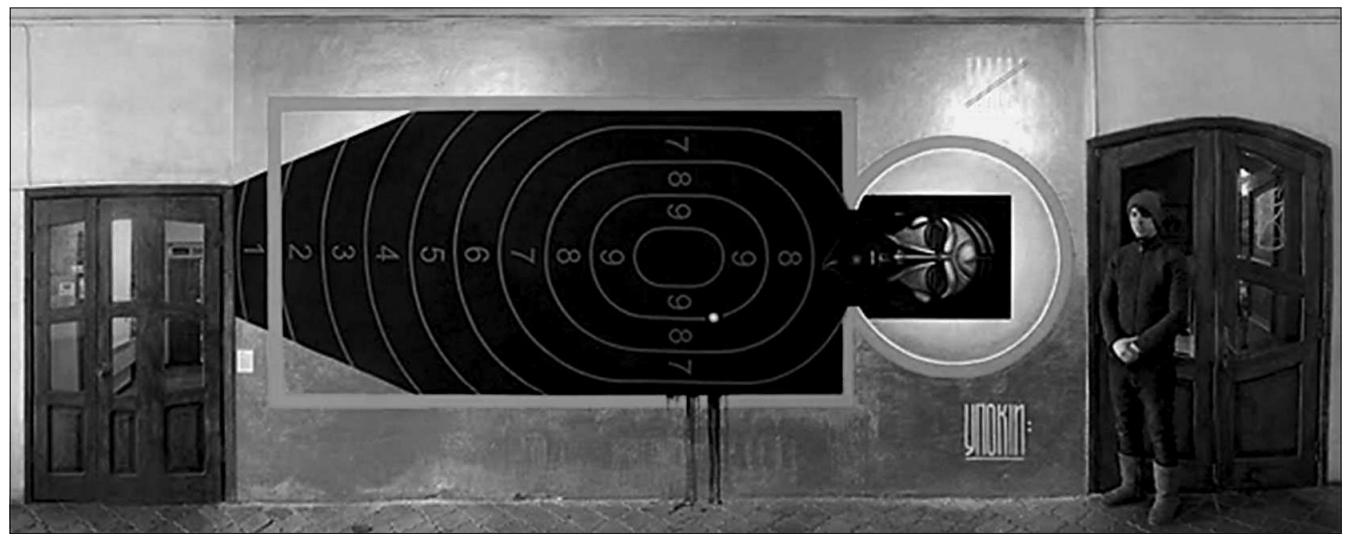

Fig. 16. S. Radkevych. «Sergei Nihoyan. Armenian motif». From the cycle «Rest in peace». 2014.

we see the social body coming back to life - a community of people. But Maidan can not be permanent" (Горящие покрышки и стук палок по железу - Майдан в Санкт-Петербурге).

The process of Maidan's events has some features of mythologizing. Thus, the Maidan stands a battleground between Good and Evil, and its members - the protesters, government officials, troops of "Berkut" and security forces, journalists, volunteers and other people play there a key role. An interesting and definitely an important symbolic process of the revolution protest were burning tires and so-called "dialogue" of the protesters with "Berkut", made in various performance ways: fighters were asked to go over to the peoples side, people offered them flowers and painted their shields in yellow-blue colors.

The most astonishing and tragic works were created by artists after the January events on the Hrushevskoho street, when the first victims of unknown snipers appeared. Several works were devoted to one of the victims, an Armenian young man Sergei Nihoyan, who became the modern incarnation of the protesters love of Ukrainian culture. Among them - mural painting made by street art artist from Lviv Sergey Radkevych. "Sergei Nihoyan. Armenian motif (see Figure 16)" - a first portrait created for the cycle "Rest in peace" dedicated to the victims of the recent events in Ukraine. In this art-work an activist Sergei Nihoyan was portrayed as a symbolic target, and at the same time reminds the iconographic suffering image of Christ, who brought himself as a sacrifice for his people. "It is a work that rises from the horizontal plane and moves in a vertical to glorify the image of today's martyrs" - says the artist (Sergatskova, 2014).

In addition to military busts targets, the artist depicts the silhouette and a portrait, carved before on tombstones in Armenia, where Sergei Nihoyan came from. "With this painting I express a personal protest against the directed and deliberate aggression against the human body, the absurdity of »human body « used in military exercises. Being inanimate, this aggression carries the sign of the living entity and brings a real sacrifice. This work was created in memory of those who suffered from deliberate violence" (Sergatskova, 2014).

The tragic perception of life as a battle is presented in the works of early 2014, reflected the events of 18-20 February. After the mass shooting of activists and ordinary passers-by by snipers, a number of art-works were created, which expressed grave pain of loss, frustration, devastation of war and anger at those responsible for the deaths of unarmed 
protesters. All the dead from bullets during the Ukrainian fighting were called "The Heaven's Hundred", and that made them almost the saints. Works devoted to the tragic events of the February are astonishingly tragic. Here we see the new Maidan as an epicenter of fighting and bloody massacres. New heroes of these works are the dead of «The Heaven's Hundred» (see Figure 17).

The events of Euromaidan made a reaction of artists from other countries who presented their views on the situation in Ukraine in their works of art and events. Thus, the Polish artist Kaśka Czapska after the fighting in the center of Kiev created a poster - stars of the flag of united Europe became the bullets holes on the flag of Ukraine - a reminder of what a terrible sacrifice Ukrainian people made for their desire to enter the European Union (see Figure 18).

Among the works of Russian artists there were an interesting and symptomatic artistic event for a support of the multiplicity of "Freedom", which was held February 23 in St. Petersburg while the hearing of detained Russian protesters on the Bolotnaya street (see Figure 19).

Organizer artist Peter Pavlensky explained his creative vision: "Hot tires, Ukrainian flags, black flags and crashing blows on iron - a song of liberation and revolution. Irreversibly Maidan spreads and penetrates into the heart of the Empire. That it is an event of plurality, this is an action of a collective body. Fighting with the imperial chauvinism continues - the church of the blood of the Saviour, the place where a successful attempt to kill the emperor was made, where liberation uprising in Right Bank Ukraine was severely dealt with, in Poland, Lithuania and Belarus. We

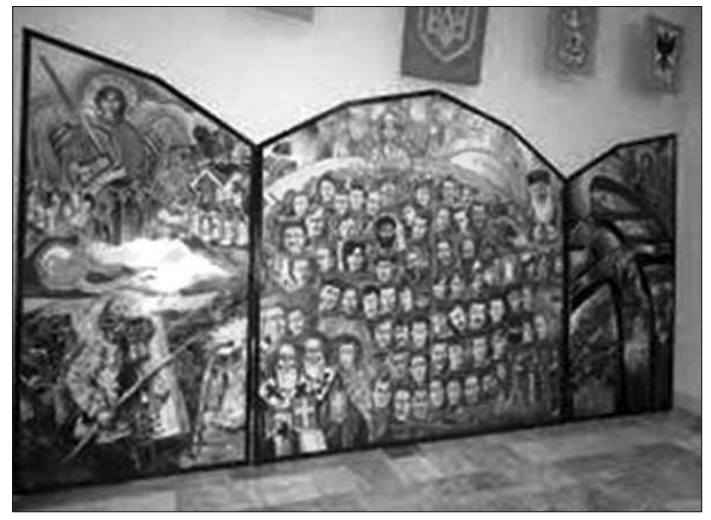

Fig. 17. R. Bonchuk. «The Heaven's Hundred». Icon. 2014.

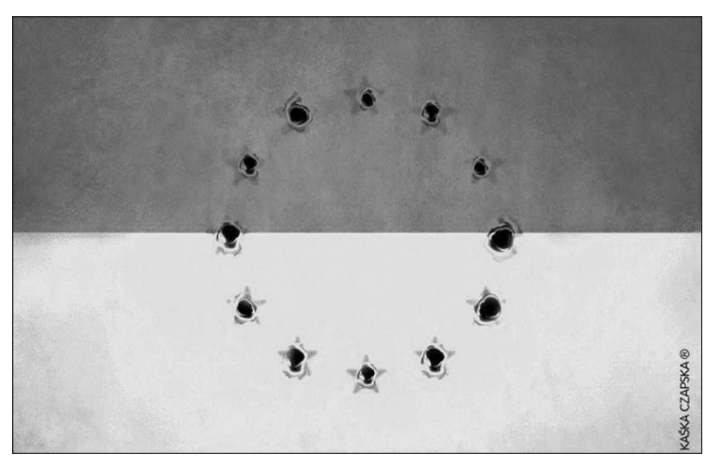

Fig. 18. K. Czapska. «Ukraine». 2013.

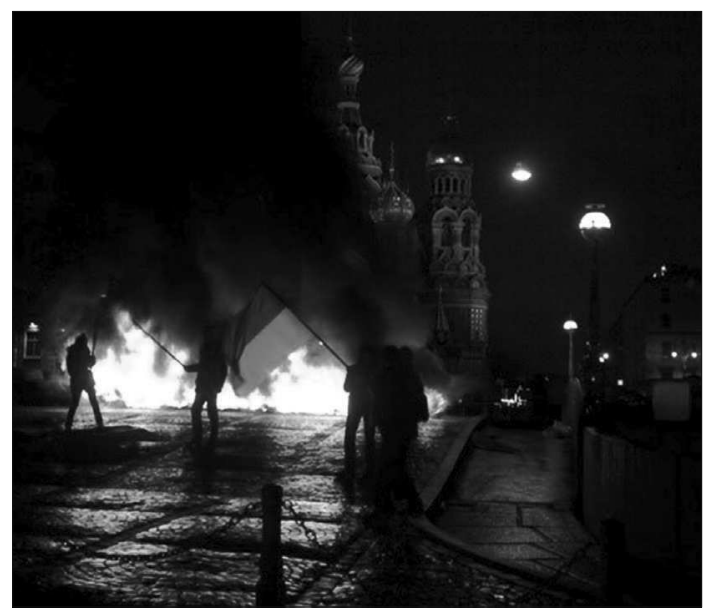

Fig. 19. P. Pavlensky. «Maidan». Action in StPetersburg, Russia. 2014. 
are fighting for our freedom and yours. Today, when the state encourages all to celebrate the fatherland Defender's Day, we encourage everyone to feast on the square defending their freedom. Bridges are burning and there's no way back" (Sergatskova, 2014).

\section{DISCUSSION}

Critics try to explain such a great resonance of Maidan's art and point to the long lasting connection between art and politics. V. Ibrayeva notes, that "aesthetics of protest has a rather long history - starting from the red Phrygian cap and the Marseillaise of the French revolution to movement «Wear national» by Mahatma Gandhi".

Boris Groys observes that art has always included some political representation, and that art itself traditionally acted like a background and a pattern for political power. However, in contemporary art this relationship between art and politics has changed considerably due to the transition of art into the political arena. Earlier system of political and artistic representation were separated one from another, but now, in the era of media, every politician can become a bright and public art-person, who generates significantly more pictures and images than an artist, by creating his own performance. Similarly, the artist enters the arena of a politician and uses his instruments. In B. Groys opinion, producing of a memorable image of any media-persons, politician or artist, starts with the creation of a collision or conflict situation (Groys, 2004).

This is the image that is expressed in the form of conflict, and is, according to art historians, "the contemporary media icon in the form of controversial". This is the "icon of space" where exists the ideological struggle, where the variety of modern propaganda machines operate in the same manner as the propaganda machine of the church "- said B. Groys. That is why the icon, as well as modern media icon, is political by its nature. And this is how, according to art historians, a contemporary art becomes political. If the image shows nothing (not mimetic), it cannot be criticized, because any criticism involves the comparison. Outside of established museums and galleries, artists of political protest make their expression across the street (Groys, 2004).

Here are represented the biggest number of important artistic events and performances. One of the most interesting features of this type of contemporary art - dynamics, variability, transformativity. It can be seen in the protest performances and art events of Euromaidan, in projects of Ukrainian art-groups "R.E.P.", "SOS'ka" and others, where the desire for freedom of expression made the basis for the creation of large art form.

The artistic value of Euromaidan art appears in it. Euromaidan presents the living process, a kind of creative act of human rebelliousness - it constantly changes and transforms. As a collective creation, the art of Maidan was intended to reveal personality in human, revive the desire to overcome the stability and conditionality of imposed roles.

\section{CONCLUSIONS}

One of the most marking features of contemporary Ukrainian art of the 2000's was the actualization of political issues in various kinds of creation. The most visible was expressed during the events of 2004 and 2013-2014 years, known as "Maidan" (2004) and "Euromaidan" (2013). Growing of artists interest in political subjects was observed since 2004, when in Ukraine it has increased democratic tendencies, and not only de jure but also de facto, free expressions had become possible. 
The most striking manifestation for the democratization of art, which has always been a political tool in Ukraine, became the creation of critical works of art, art events, formation of a number of socially and politically oriented youthful artistic groups having their citizen position and considering the main goal of their work to draw attention of the public to political events. Today we can say that these groups gradually made an influence on the creation of the artistic medium.

The real awakening of public awareness arose from the art-events of Euromaidan, which showed striking changes in the social, political and cultural life of Ukraine. The brightest objects of Euromaidan - Kiev City Christmas tree (with symbols of the European Union and the Ukrainian flag), orange miner's caps, painted like Easter eggs, colorful hand-made and printed propaganda posters, original colored stickers "Euromaidan - is ...", ironic cartoons, art projects, performances and flash-mobs. These events showed a creation in Euromaidan's space of the creative progressive cultural and artistic environment, of large performance, the protagonist of which was the Maidan itself - the spontaneous and unpredictable collective body of the creative people, united and acting, however, like one and having the same goal.

The event had its own symbolism and mythological meaning. This fact can be confirmed by international resonance: events resembling "Maidan" were repeated in other countries, but mostly in Russia, whose inhabitants are experiencing the same problem. All these events greatly influenced the development of contemporary art in Ukraine: the awakening and creation of a politically conscious society and adequate citizen position, without which a further cultural development of the state is impossible.

\section{REFERENCES}

Balashova, O., German, L., \& Lanko, M. (Балашова О., Герман Л., Ланько М.) (2013). Арт-итоги года. Часть 1 [Art-result of the year. Part 1]. «Ukrayinska pravda», Kyiv. Retrieved December 26, 2013 from http:/ / life.pravda.com.ua/culture/2013/12/26/147291.

Daniuk, I. (Данюк, I.) (2005). Мистецтво Майдану побачить світ [The Art of Maidan will see the world]. «How are you doing, Куiv?» [Як справи, Київ?]. Retrieved January 12, 2005 from http:/ / kakdela.kiev. ua/17414/art/1905.html.

Groys, В. (Гройс Б.) (2004). Искусство. Дизайн. Политика. [Art. Design. Policy]. The „Art of Moscow”. Lecture.

Ibraeva, V. (Ибраева, В.) (2013). Майдан и его искусство [Maidan and its art]. Buro 247, Kazakhstan. Retrieved December 12, 2013 from http://www.buro247.kz/culture/expert/iskusstvo-maydana.html.

Kriventsova, А. (Кривенцова А.) (2008). «SOS'ка» между акцией и институцией [SOS'ka between action and institution]. Electronic Art journal [Художественный журнал]. Москва [Moscow], № 67-68. Retrieved January 30, 2008 from http://xz.gif.ru/numbers/67-68/soska-krivencova.

Ridny, N., \& Kriventsova, А. (Ридный Н., Кривенцова А.) (2009). Перспективы лабораторности [Perspectives of laboratority]. Electronic Art journal [Художественный журнал]. Москва [Moscow], № 73-74. Retrieved August 30, 2009 from http://xz.gif.ru/numbers/73-74/ridny/\#name1.

Sergatskova, К. (Сергацкова К.) (2014). Художник створив роботу «Сергій Нігоян. Вірменський мотив» [The artist created the work «Sergiy Nigoyan. Armenian motif»]. «Ukrayinska pravda», Kyiv. Retrieved February 12, 2014from http://life.pravda.com.ua/culture/2014/02/12/152028.

Горящие покрышки и стук палок по железу - Майдан в Санкт-Петербурге [Burning tires and banging sticks on iron - Maidan in St. Petersburg]. Retrieved February 23, 2014 from http://censor.net.ua/photo_ news/272418/goryaschie_pokryshki_i_stuk_palok_po_jelezu_mayidan_v_sanktpeterburge_fotoreportaj. 